\title{
A Note on the Incest Taboo: The Case of the Matrilineal Khasis
}

\author{
Davina Diengdoh Ropmay \\ (Research Scholar, Department of Sociology, North-Eastern Hill University, Shillong, Meghalaya, India)
}

\begin{abstract}
Incest Taboo serves as one important aspect under kinship studies. Understanding the rules prohibiting intimate and sexual relations with certain kin throws light on how other facets of a social organisation operate such as marriage, clan organisation and kinship terminology. The existence of the Incest Taboo among the Khasi, a major matrilineal tribal group of Meghalaya, provides us a picture on how such facets are determined. Therefore, this article attempts to describe the bounds of the incest taboo among the Khasis and the serious implication it has towards the maintenance and perpetuation of the society as a whole
\end{abstract}

Keywords: Incest, Exogamy, Incest Taboo, Marriage, Khasi.

\section{INTRODUCTION}

The study of Kinship has been a much researched area in sociological and social anthropological studies. It simply seeks to understand on one hand, in what way a person is related to another, and on the other hand, in what way do these people exhibit behaviour with each other as per their relationship. Radcliffe-Brown rightly puts it "A kinship system thus presents to us a complex set of norms, of usages, of patterns of behaviour between kindred" (Radcliffe-Brown 1950: 10). Behaviour patterns which stem out of the social relations between people, customs, norms and usages are important for the functioning of the social machinery. On this basis, kinship is thus used to further understand how the social organisation of a particular society is determined. This social institution is a broad area in itself and it is seen to be intertwined with different aspects for which scholars have been dwelling much into, such as descent, succession, marriage, terminology, all of which are socially significant. Another one of these aspects is the Incest Taboo to which this paper attributes its discussion to. However the same does not so much aim at providing an analytical study on incest taboo, but through a collection of works, attained from secondary sources such as books and journals, this paper is rather a description of it and of the role it plays in framing the kinship system and the social structure as a whole; and as an example, we will see what importance and meaning it has in the case of the Matrilineal Khasis of Meghalaya.

\section{What is the Incest Taboo?}

\section{THE INCEST TABOO}

A keen interest in the incest taboo spans the history of human studies and bridges such disciplines as cultural anthropology, sociology, evolutionary biology and psychology (Leavitt 2013: 45). The word 'incest' refers to sexual relations with primary kin and to certain non-primary or extended kin as well. The definition given by Notes and Queries on Anthropology (1951) and cited by Seligman (1950) as well is as follows, incest is "sexual intercourse between individuals related in certain prohibited degrees of kinship" (Notes and Queries 1951:113). According to Murdock, socially considered, any act of sexual intercourse may be regarded as falling into one of seven major categories. Of those, if its participants are related to one another by a real, assumed, or artificial bond of kinship which is culturally regarded as a bar to sex relations, it is classed as incest (Murdock 1949: 261). Now the word 'taboo' indicates a ban or a prohibition. Joining the two words, incest taboo denotes a ban on sexual relations with close kins. Scholars have sought to define the 'incest taboo'. The incest taboo in any society consists of a set of prohibitions which outlaw heterosexual relationships between different categories of kinsmen (Aberle et.al 1971: 346). According to Murdock, incest taboos prevent sexual intercourse or marriage between persons who are believed to be closely akin, whether they are actually close relatives or whether the kinship bond between them is merely a conventional one (Murdock 1949: 267). The most distinctive feature of the incest taboo is the regulation of erotic relationships, within the family and in relation to the establishment of new families (Parsons 1954: 109). This social and cultural rule, regulation or norm of prohibition of sexual relations between primary categories of kin has an implication on the organisation of the wider kinship system and social structure. The prohibition of incest constitutes a rule, which, alone among social rules, possesses at the same time a universal character (Levi-Strauss 1969: 8). Incest Taboos appear to be present in some form universally, though their exact range varies considerably from society to society (Parkin 1997: 37). 


\section{Theories of the Incest Taboo}

Given the diversity of academic interests it is not surprising that explanations of the incest taboo have taken very different directions (Leavitt 2013: 1). We can accredit the theoretical explanation of the incest taboo firstly to the Finnish sociologist Edward Westermarck who in his major work 'The History of Human Marriage' in 1891 enumerated on the reason of the prevalence of the Incest Taboo. That reason was known as the 'instinctive aversion to incest'. Westermarck maintained that, there is an innate aversion to sexual intercourse between persons living very closely together from early youth, and that, as such persons are in most cases related, this feeling displays itself chiefly as a horror of intercourse between near kin (Westermarck 1891: 320). This denotes that our avoidance of incest is purely based on an inner, inborn, natural tendency. Children brought up together form a sentimental connection and attachment that is by its nature non-erotic or non-sexual. Westermarck's explanation of avoidance of incest correlated with natural

selection, in that the former was a product of the latter. Through natural selection an instinct must have been developed, powerful enough, as a rule, to prevent injurious unions. This instinct displays itself simply as an aversion on the part of individuals to union with others with whom they have lived, but as these are for the most part blood-relations, the result is the survival of the fittest (ibid. 546). He also denoted further that there would be biological harm as a result of close inbreeding, in other words a negative effect on the children of such a union. Incest was thus defined and prohibited because inbreeding causes biological degeneration (White 1948: 417). This degeneneration theory was championed by others like Lewis Henry Morgan (1877) as well.

Edward Tylor also gave his views with regards to the incest taboo in terms of his 'alliance theory'. To him, different kinship groups and communities were tied together in mutual aid for survival through the marital and sex rules, which required persons to have relationships outside their kin community. As has been noted by Leavitt, in modern parlance, Tylor's "savage" societies would be recognized as nomadic hunters and gathers and simple agricultural peoples. Such societies, organized around family groups and kinship lineages, enhance their survival and well-being if they abide rules which require their members to make associations outside of their immediate kin communities. While other kinds of cooperative alliances can occur to the same ends, marriage and sexual prohibitions are especially affective in compelling individuals to connect with outside persons and communities (Leavitt 2013: 46).

Durkheim attempts to explain the prohibition of incest as a part of his general theory of totemism in his article on incest entitled as 'La prohibition de l'inceste et ses origines' published in L'Anée Sociologique in 1898. The savage knew intuitively, Durkheim reasoned, that blood is a vital fluid or principle. To shed the blood of one's own totemic group would be a great sin or crime. Since blood would be shed in the initial act of intercourse, a man must eschew all women of his own totem. Thus the taboo against incest and rules of exogamy came into being (White 1948: 420).

Last but not the least; mention has to be made of the 'natural desire' theory which is associated with the view of Sigmund Freud. According to this theory, we all have incestuous desires within us, but however we repress them, in other words we hold them back and not act upon them. Thus in the primeval situation, the young males of the horde killed off the old male in order to get at the females he monopolized. But because they had been conditioned to obey him, they felt remorse and guilt about this and so renounced the females. We have been guilty about it ever since, and so although we still have incestuous desires, we repress them through the mechanism of our inherited guilt (Fox 1967. 60-61).

Thus, there is evidence that people unconsciously choose mates who are bit different from those individuals who are familiar from early life (Bateson 2005: 24).

\section{Incest and Exogamy}

Strictly, there is a difference between the terms 'Incest' and 'Exogamy'. The former pertains to sexual relations while the latter pertains to conjugal or marital relations. They are not the same, as they refer to two different kinds of relations. Robin Fox stressed on this matter of distinction. He points that if one forbids two people to have sexual relations, this rather puts an end to chances of marriage between them, but one can forbid them to marry without necessarily forbidding them to have intercourse (Fox 1967: 55). However despite the fact that the two terms are different, it is noted that there is a high correlation between the incest rule and the rule of exogamy. Infact the terms exogamy and incest taboo have been used interchangeably. In general, exogamy has a reference to marriage and incest to sex, but "in practice the two are linked in terms of the persons barred from both marital and sexual relationships" (Leavitt 2013: 45). In every society there are rules prohibiting incestuous relations, both as to sexual intercourse and recognized marriage (Notes and Queries 1950: 113). It has been proposed that both marital and sex rules, necessitate persons to not have relationships within their community of blood relations. According to Murdock, closely related to the incest taboo are the rules of exogamy that usually prohibit marriage between the same categories of kin forbidden by incest rules. Incest taboos and their extensions in the form of exogamous rules ordinarily require a person to marry outside of his own consanguineal kin group, with the result that spouses are normally members of different groups (Murdock 1949: 42). LeviStrauss also claimed that the effect of incest taboo is to encourage exogamy. Considered as a social institution,

DOI: 10.9790/0837-2205014146 $\quad$ www.iosrjournals.org $\quad 42$ |Page


the prohibition of incest has two different aspects. Sometimes it is only a prohibition of sexual union between close consanguines or collaterals while at others this form of the prohibition, based as it is upon a definite biological criterion, is only one aspect of a broader system which is apparently without any biological basis. In many societies the rule of exogamy prohibits marriage between social categories which include near relatives, but, along with them, a considerable number of individuals for whom it is impossible to establish all but the most distant consanguineous or collateral relationships (Levi-Strauss 1969: 19). Levi-Strauss also notes Durkheim's view on the incest taboo in that for the latter, the prohibition of incest is a remnant of exogamy (ibid. 20).

\section{Direction of the Incest Taboo}

Now in reference to the people for whom taboo is directed to, who are 'close kin', 'close relatives', 'people related in degree of kinship' is not same in all societies and cultures. Almost universally prohibitions on sexual relations include those between primary kins, that is, between brother and sister, father and daughter, mother and son. With the exception of married parents, incest taboos apply universally to all persons of opposite sex within the nuclear family (Murdock 1949: 284). Parsons (1954) mentions that the nuclear family is universal to all known societies and it has certain characteristics out of which one of them is the essentiality to the family that overt erotic attraction and gratification be given an institutionalised place in its structure. He further says, when we say this is institutionalized we mean that eroticism is not only permitted but carefully regulated; and the incest taboo is merely a very prominent negative aspect of this more general regulation (Parsons 1954: 104). But even in this regard, in certain societies incest between primary kin within the nuclear family is not seen to be something that is frowned upon but allowed. No society is known where incest between mother-son, fatherdaughter or full brother-sister is permitted except the few cases of brother-sister marriage in royal families, but never for the bulk of the people. There are a few cases of marriage permitted between half-brother and halfsister, and similar cases of closeness, but only a few (ibid. 101-102). Brother-sister marriage in Roman Egypt has long been noted as a conspicuous exception to near-universal taboos against regular sexual and marital relations between very closely related kin (Scheidel 2005: 93). Hopkins notes that in the Egyptian Royal family, brother-sister marriages have been known as far back as the eleventh dynasty in about 200 B.C. (Hopkins 1980: 311). Ptolemy II, in effect the second Greek king of Egypt, divorced his wife who had borne him several children and married his full sister Arsinoe, when she was just under 40 years old and he was about 30 years old (ibid. 311). One of the explanations for such incestuous relations in ancient Egypt was to preserve the lineage. This was noted among the royals. Also Hopkins notes that Egyptians may have thought or believed that a brother-sister marriage would be economically advantageous, for example, the marriage ceremony might be less expensive: only one set of relatives to invite, the family lands would be kept intact, and so the family would be saved the costs of sub-dividing the house and of working fragmented land (ibid. 322). E. E. Evans-Pritchard (1974) presented a case as well of brother-sister incest when writing about the African Azande.

One's primary kin are one's mother, father, son, daughter, brother, sister belonging to one nuclear family. However certain non-primary relatives are also tabooed while still some are encouraged. Non-primary kin would be ego's relatives outside his or her nuclear family but who are still related to ego either through consanguineous or affinal ways. In the broad discourse of social anthropology much has been discussed on the existence of cross-cousin marriages in certain parts of the world which seek to provide an exception to the incest taboo from operating against the so called cross-cousins. Non-primary kin would also include members belonging to descent groups such as clan or sub-clan, phratry, gotra, all tracing their descent from the same ancestor or ancestress. All in all, the direction of the incest taboo, in terms of who are the people it is directed to, lies in accordance with the social organisation or structure of different societies. While some approve of incestuous relations in the name of preserving lineage along royalty lines, others denounce it. Again in some societies the extent of incest taboo is directed only to primary, immediate blood kin while others include nonprimary kin as well.

\section{THE MATRILINEAL KHASIS}

The Khasis are a matrilineal people residing in the North-Eastern state of Meghalaya, India. The term Khasi means born of the Mother; 'Kha' means born and 'Si' refers to "ancient mother" (Augustine 2007: 42). A distinctive feature of Khasi society is the matrilineal principle of descent, succession and inheritance (Pakynteiñ 1996: 349). Being a matrilineal tribe, the Khasi tribal group is guided by matrilineal principles, the basic one being that descent and ancestry is traced along the mother's line. Hence the organisation of clans (kur), subclans (jait) and lineages (kpoh) all exist as per this principle, tracing their origin to a common ancestress. Clanship system among the Khasis exists along certain lines - firstly is the prevalence of clans based on descent from a common ancestress, so all members are blood related or are consanguines. They attribute the word Shi Kur (meaning single or one clan) to refer to one another; secondly we can talk of ka ting kur (a reference to the word ting-khun which means to own a child as one's own). Here one clan is adopted by another as a cognate 
clan; thirdly we can talk of kam kur (professed kin) and iateh-kur (kur/clan binding) where a clan is adopted as blood relations. This usually happens when one kur feels obligated to another kur because of the latter's help or of close friendship between the two. This further has relevance with the jait or sub-clan. Different jait have different origins. To put it more elaborately, the members can be associated under one kur by the process of kurbinding or iateh kur in which jait or sub-clans are bound by covenants or agreements to be in one kur. It is in the light of this that jait plays a role in kur formation. Understanding clan organisation serves as a background for further seeing the implication of the incest taboo in the Khasi society.

\section{Concept of Taboo or 'Sang'}

Among the Khasis the word 'sang' in general, indicates taboo. A thorough explanation of this word is imperative. The word sang may be translated to mean taboo which means anything forbidden or prohibited by society and violation of these taboos is met with punishment. However according to Khasi thought and philosophy it also relates to the deeper essence of sanctity and performance and observance of sacrifices, rites and rituals which thus shows punishment for breach of taboos as having divine implication. As has been put by Mawrie Ka Sang is very much feared by a Khasi not because of the punishment, but because it brings down the curse of God upon a person and upon his/her kur. Thus it is more of a psychological punishment based on religious belief (Mawrie 2014: 47). In general the Khasis as per their beliefs consider certain things as sang, or in other words those which fall under the category of being prohibited or proscribed. Sang has played an important role in guiding the lives of the Khasis in all their endeavours.

\section{The Incest Taboo in the Khasi Society}

Among the Khasis, marriage is regulated by certain rules which act as guiding principles for the selection of life-partners. The concept of free marital choice or selection is regarded to be relative as such rules or guidelines govern who one should marry. Meticulous calculations are made before any marital union could be established. The Khasis are strictly exogamous, that is, pertaining to marriage outside the group, and in this case the group is the kur or clan. It is considered a great crime to marry within one's clan, that is, families having the same ancestress or Iawbei. It is considered 'sang' or taboo. In this regard, one can say that the rule of exogamy operates in the Khasi society.

In relation to the word "incest", it is indicated by the words ka sang ka ma and the word shong-sang is used to mean having an incestuous relation. The concept of the incest taboo among the Khasis is one which is of utmost importance. It is seen to be a negative rule, which when going against it, serious consequences would follow. Although strictly the word 'incest' pertains to sexual relations with primary or close kin or relatives, however this word extends to include marital relations as well with the said kin for which taboo is directed to. Thus among the Khasis the rule of the incest taboo is congruent with the rule of exogamy, hence defining the bounds to which the Khasi social structure is to be organised. In the light of this, this rule is concurrent with the much significant matrilineal maxim of ' kheiñ-kur khieñ-kha' or 'tip-kur tip-kha', in other words considering and knowing one's maternal (cognates) and paternal (agnates) relations. The extent to which the incest taboo is to be directed to, does not involve only from the kur or maternal relations but likewise from the kha or paternal relations.

As have been mentioned in the previous paragraph, clan exogamy is one of the basic rules governing the Khasi marriage institution. Marriage between cognates is considered to be an incest (War 1989: 5). Whether these cognates trace their descent from the same ancestress, or whether their clans may be related through joint agreements or whether through one being adopted as a cognate clan to the other, incest taboo applies to all of them.

For almost all maternal relations (kur), incest taboo is directed against them. However there is an exception with the instance of cross-cousin marriage that is seen to be more or less possible or allowed but however not preferred. An individual cannot have a marital or sexual relation with his/her parallel cousins, i.e. an individual's mother's sister's children. The reason is because these children have membership in the same clan. So it is taboo. Coming to cross-cousins, it is somewhat a different picture. In relation to prohibited degrees of relationship, the Khasis are known to have an aversion to cross-cousin marriage. However at the same time, the Khasis have never institutionalised the rule of cross-cousin marriage. Among the Khasis, theoretically there is no bar to the nephew marrying his maternal uncle's daughter since a man's children belong to the clan of his wife. However such cases are few and far between. A man can enter into a marital union with his matrilateral cross-cousin, i.e. his mother's brother's daughter but only after the death of the said brother. According to Gurdon, a Khasi cannot marry his maternal uncle's daughter during the lifetime of the maternal uncle (Gurdon 1975: 78). This tacit prohibition is attributed to the nature of the Khasi iing, because the maternal uncle is regarded more in the light of a father-figure than that of an uncle, i.e. merely a mother's brother. Reasons to the possibility of cross-cousin marriage is the fact that firstly, the individual and his cousin belong to two different clans. Secondly, given that the maternal uncle is much respected by his nephew, if from the same iing, they (men) enter into marriage into the same clan outside theirs, it is said the nephew is following his uncle and they 
revere it as something good among the Khasis. Thirdly, reason for possibility lies in the designation of kinship terms. It is noted that the maternal uncle calls his sister's children as pyrsa, similarly parents call their children's spouse as pyrsa-kurim. In this context, Nongbri noted that although by itself the word pyrsa does not refer to an affinal relation, careful examination shows the term is highly suggestive of it (Nongbri 2013: 425) The male ego's sister's children are called pyrsa, which is a root word for the son/daughter-in-law (pyrsa kurim), a first order affinal category (ibid. 425). Hence this points to the possibility of matrilateral cross-cousin marital union. However at the same time, with cross-cousin marriage there emerges certain problems such as identification of the ties of kinship. The same person will be both uncle and father-in-law while the one who marries his uncle's daughter becomes both nephew and son-in-law. Hence such unions when established, although they are not strictly taboo, they are looked down upon with disfavour.

As equally imperative as the prohibition placed against incestuous unions with maternal relations, is the same placed with paternal relations $(k h a)$. Once a marital union is established between two clans and children are born, relations become as primary and as close. This is so true when we talk about paternal relations. Children have utmost respect and reverence for their father's mother (meikha) and sisters (niakha) because it is the father's clan that begets those children and provides them their stature and form. The respect that the children, as the progeny begotten by the father's natal family ( $k i k h u n k h a$ ) give to the paternal relations, especially to the grandmother and father's sisters is one that is very significant among the Khasis. Hence when we talk of incestuous unions, the one directed towards paternal relations is seriously observed and taken into account. It has been mentioned that matrilateral cross-cousin marriage from the male perspective is possible among the Khasis, however the same cannot be said of patrilateral cross-cousin marriage, when speaking from a male perspective, that is, the marital union between a man and his father's sister's daughter. This is one of the serious taboos among the Khasis. It is noted that the father becomes the progenitor; he and his natal clan become the giver of the 'seed' of life for his children. Also upon marriage, a man brings with him his earning (ka kamai) so that he can sustain his wife and children. Hence if a marriage happens between a man and his father's sister's daughter, it is said that the former is seen to be returning and reversing back those gifts received from his father to his father's family, which would thus make the said gifts and the relation as a whole as null and void. The Khasis express serious unfavour for this kind of marital union and they denote it by using a phrase-'ka ai khaw kylliang'. Literally this phrase means 'the exchange of rice'. Here rice is understood as a metaphor. Nongbri clearly explains this in that by using the symbolism of rice and portraying it as an irreversible element in marital relations, the Khasi not only seek to emphasise the fundamental importance of the father's physiological, but also his economic contribution to his children. This is further explained, in that, the metaphor expresses that the contributions made by the father to the life and personhood of the child cannot be repaid or returned and any attempt to do so can only be a brash and arrogant act (ibid. 417). With regards to patrilateral parallel cousins, marriage is also not allowed between them. When talking about sons, these have been begotten by the same mother whose blood from her umbilical cord flows through their veins. As these sons get children through marriage into other clans than their own, these children become to be known as shipara kha which means that they are equated as direct siblings since their fathers have come out and emerged from the same umbilical cord of their paternal grandmother, who begot her sons. Also these sons get their stature from their mother, which is then passed down to their children. Under such degree of prohibitory relationship from the side of the father, all in all, the Khasis denote the phrase - 'Sang Sohpet-Kha', here sohpet means the umbilical cord, kha indicates paternal relations. It thus denotes taboo directed to members of the patrilineal blood line. In general thus a Khasi avoids any kind of incestuous relation with those members who are very closely related through being connected by the same umbilical cord of the paternal grandmother.

Among the Khasis, consequences are met and directed to those who indulge in incestuous relations. In earlier times, a couple would be looked at with utmost shame and disgrace and they would be ostracised and excommunicated from their respective clans as well as from the community as a whole. The seriousness of the incest crime within a clan was so serious that anyone guilty was punished severely, by being physically and socially excommunicated, disowned by the clan and the community, without rights to property. A couple who has transgressed $\mathrm{ka}$ sang $\mathrm{ka} \mathrm{ma}$ (incest) was usually driven out from the village to live in isolation forever. As noted by War, this isolation was not only for the present life but also for the life hereafter... (War 1989: 6).

\section{CONCLUSION}

Every society has their own rules or guidelines pertaining to marital choice or selection of spouse, in other words whom one should mate with and whom one should not. It is these rules that maintain the structure of the society and any deviant behaviour otherwise would result in serious penalties and disturb the order of the social structure. This is true of the Khasi society which places a lot of importance on the incest taboo or ka sang ka ma. The existence of the incest taboo is seen through the rule of clan exogamy being stressed in the Khasi society, where marriage within the same clan (kur) which identifies maternal relations is proscribed. The taboo extends itself to paternal relations ( $k h a)$ as well and one could note that this is also equally important to keep in 
mind. The totality of the implication placed on the kur and kha relations rests also on the various kinship terms assigned to the said relations. Thus both maternal and paternal relations are considered when speaking about whom incest taboo is directed to and all this points to one of the important matrilineal tenet that all Khasis must adhere to - Tip-Kur Tip-Kha.

\section{REFERENCES}

[1] Radcliffe-Brown, A.R. and Forde, Daryll, African Systems of Kinship and Marriage, (New York: Oxford University Press, 1950)

[2] Leavitt, Gregory C., Tylor vs. Westermarck: Explaining the Incest Taboo, Sociology Mind, 3(1), 2013, 45-51.

[3] Notes and Queries on Anthropology: A Committee of the Royal Anthropological Institute of Great Britain and Ireland. (London: Routledge and Kegan Paul, 1951).

[4] Seligman, Brenda Z., The Problem of Incest and Exogamy: A restatement, American Anthroplogist, 52, 1950, 305-316.

[5] Murdock, George Peter, Social Structure, (New York: The MacMillan Company, 1949).

[6] Aberle, David F; Miller, Daniel R; Bronfrenbrenner, Urie; Schneider, David M; Hess, Eckhard H; Spuhler, James N., The Incest Taboo and the Mating Patterns of Animals, in Nelson Graburn (Ed.), Readings in Kinship and Social Structure, (New York: Harper and Row Publishers, 1971) 346-355.

[7] Parsons, Talcott., The Incest Taboo in Relation to Social Structure and the Socialization of the Child, The British Journal of Sociology, 5(2), 1954, 101-117.

[8] Levi-Strauss, Claude, The Elementary Structures of Kinship, (Boston: Beacon Press, 1969).

[9] Parkin, Robert, Kinship: An Introduction to Basic Concepts, (Oxford: Blackwell Publishers, 1997).

[10] Westermarck, Edward, The History of Human Marriage, (London: Macmillan and Co., 1891).

[11] White, Leslie A., The Definition and Prohibition of Incest, American Anthropologist, 50(3), 1948, 416435.

[12] Morgan, Lewis Henry, Ancient Society, (Chicago. Charles H Kerr \& Company, 1877).

[13] Fox, Robin, Kinship and Marriage: An Anthropological Perspective. (Harmondsworth, Middlesex, England: Penguin Books Ltd., 1967).

[14] Bateson, Patrick, Inbreeding Avoidance and Incest Taboos, in Arthur P. Wolf and William H. Durham (Ed.), Inbreeding, Incest and the Incest Taboo, (California: Stanford University Press, 2005) 24-37.

[15] Scheidel, Walter, Ancient Egyptian Marriage and the Westermarck Effect, in Arthur P. Wolf and William H. Durham (Ed.), Inbreeding, Incest and the Incest Taboo, (California: Stanford University Press, 2005) 93-108.

[16] Hopkins, Keith, Brother-Sister Marriage in Roman Egypt, Comparative Studies in Society and History, 22( 3), 1980, 303-354.

[17] Evans-Pritchard E.E (Ed.), Man and Woman among the Azande, (New York: The Free Press, 1974).

[18] Augustine, Celine, and Matriliny in Tansition: A Comparative Analysis, (New Delhi: Akansha Publishing House, 2007).

[19] Pakynteiñ, Valentina, the Khasi Clan: Changing Religion and Its Effect, in J.S. Bhandari (Ed...), Kinship and Family in the North-East, (New Delhi: Cosmo Publications, 1996) 349-71.

[20] Mawrie, Barnes, Khasi Ethics, (Shillong: Vendrame Institute Publications, 2014).

[21] War, Juanita, the Incest Taboo and Clanship System among the Khasis, Khasi Studies, III (1), 1989, 4-11.

[22] Gurdon, P.R.T., the Khasis, (Delhi: Cosmo Publications, 1975).

[23] Nongbri, Tiplut, Kinship Terminology and Marriage Rules: The Khasi of North-East India, Sociological Bulletin, 62 (3), 2013, 413-430. 